\title{
DEMOKRASI ERSATZ: MENGGUGAT PERAN PEMUDA DALAM MENGAWAL PROSES DEMOKRATISASI DI INDONESIA
}

\author{
Mahathir Muhammad Iqbal \\ Universitas Islam Raden Rahmat Malang \\ Email: iqbalz_mm@yahoo.com
}

\begin{abstract}
We already are in an open democratic stage within 17 years. However, we are also required to continue to make serious resolutions and improvements related to the character of the ideology of democracy. In many ways, we still fail to open up possibilities and alternatives in managing circulation prospective leadership and in accordance with the requirements of democracy. Fundamental changes to equip democracy needs to be done for the sake of the birth of the benefit shared values. In this context, youth should play a role. youth should proofread and guarding the democratic process in order not to handcuffed by pragmatic political interests. Moreover, if we depart from the conviction, that the youth are the leaders of future generations.
\end{abstract}

Keywords: democracy; resolution; leadership circulation

\begin{abstract}
Abstrak
Kita memang sudah berada di panggung demokrasi terbuka dalam kurun 17 tahun. Namun, kita dituntut pula untuk terus melakukan resolusi dan pembenahan yang serius terkait karakter ideologi demokrasi. Dalam banyak hal, kita masih gagal membuka kemungkinan dan alternatif dalam mengelola sirkulasi kepemimpinan yang prospektif dan sesuai dengan kebutuhan demokrasi. Perubahan fundamental untuk melengkapi demokrasi itu perlu dilakukan demi lahirnya nilai-nilai kemanfaatan bersama. Dalam konteks inilah pemuda seharusnya berperan. pemuda patut mengoreksi dan mengawal proses demokrasi agar tidak tertelikung oleh kepentingan politik pragmatis. Apalagi kalau kita berangkat dari keinsafan, bahwa pemuda adalah pemimpin generasi masa depan.
\end{abstract}

Kata kunci: demokrasi; resolusi; sirkulasi kepemimpinan

Pengutipan: Iqbal, M. M. (2015). Demokrasi Ersatr: Menggugat Peran Pemuda dalam Mengawal Proses Demokratisasi di Indonesia. SOSIO DIDAKTIKA: Social Science Education Journal, 2(2), 2015, 147-155. doi:10.15408/sd.v2i2.2817.

Permalink/DOI: http://dx.doi.org/10.15408/sd.v2i2.2817 


\section{A. Pendahuluan}

Kata-kata ersatz saya temukan pada salah satu buku Kunio." dengan judul asli "The Rise of Ersatr. Capitalism in Southeast Asia" (1987) yang digubah ke dalam bahasa Indonesia oleh LP3ES dengan judul "Kapitalisme Semu Asia Tenggara" (1990).

Dalam buku itu si pengarang mencoba untuk mengetengahkan sebuah tesisnya tentang fenomena kapitalisme di Asia Tenggara. Menurutnya kapitalisme yang menggejala di Asia Tenggara bukanlah kapitalisme yang sebenarnya, alias tulen, akan tetapi kapitalisme dalam bentuknya yang semu (ersats). Tesisnya itu didasarkan pada sebuah asumsi normatif bahwa kapitalisme yang sebenarnya itu adalah kapitalisme yang dulu pernah menggejala di Eropa dan kemudian di Amerika dan Jepang. Dan kita tahu, kapitalisme tulen itu dibesarkan oleh kebebasan pasar, kalkulasi rasional, alat produksi sebagai milik pribadi, adanya sistem hukum yang rasional, pengembangan teknologi yang rasional, komersialisasi ekonomi dan adanya buruh bebas.

Maka saya juga ingin meminjam istilah ersatz untuk menggambarkan bahwa demokrasi yang sedang kita jalani ini pada dasarnya adalah demokrasi semu. Nuansanya lebih kental demokrasi proseduralnya dibandingkan demokrasi substansialnya. Demokrasi kita hari ini adalah demokrasi yang berfilosofis gincu, yang tampak tapi tak terasa ketimbang berfilosofis garam, yang tak tampak tetapi terasa.

Dengan kata lain, meminjam istilah Piliang, ${ }^{2}$ perkembangan demokrasi akhir-akhir ini diancam tindakan, perilaku dan gerakan "kontrademokrasi", yang menggerogoti bangunan demokrasi dari dalam: korupsi, politik uang, kekerasan, terorisme, dan aneka konflik horizontal.

Sebagai legitimasi penilaian saya tentang demokrasi kita hari ini yang semu, saya ingin menggunakan instrumen pemilu sebagai salah satu indikatornya. Kebetulan hal ini

\footnotetext{
1 Y. Kunio, The Rise of Ersatz. Capitalism in Southeast Asia (Yogyakarta: LP3ES, 1987).

2 Y. A. Piliang, "Parasit Demokrasi", Kompas, Edisi 6 Oktober 2011, h.
}

menemukan relevansinya tatkala kita baru saja melewati pemilu legislatif (DPRD Kabupaten/ Kota, Provinsi, DPR RI, dan DPD) dan pemilu Presiden dan Wakil Presiden.

Sering, kalau membicarakan demokrasi di Indonesia, kita akan mulai bicara tentang demokrasi yang berlainan dengan demokrasi Barat. Demokrasi kita tidak hanya menekankan hak tapi juga tanggung jawab, dan sebagainya. Nada pembicaraan sering bersifat apologetic (membela diri), dan ini mungkin karena demokrasi di Indonesia belum berjalan dengan baik.

Budiman, ${ }^{3}$ mengemukakan bahwa memang benar, masalah mengukur gejala ada atau tidak adanya demokrasi bukanlah hal yang mudah. Misalnya, banyak orang di Barat yang mengukur ada atau tidaknya demokrasi dengan ada atau tidak adanya pemilihan umum. Pemilihan umum memang merupakan salah satu manifestasi demokrasi, tapi belum tentu dengan adanya pemilhan umum, demokrasi pasti ada. Ini menunjukkan bahwa mencari indikator dari gejala demokrasi tidak begitu mudah.

Tapi apapun bentuk sebuah demokrasi, di Barat maupun di Timur, ada ciri utama yang tidak dapat ditawar, yakni dalam demokrasi dimungkinkan adanya partisipasi dari semua golongan masyarakat. Salah satu Manifestasi dari partisipasi ini dapat berupa pemilihan umum. Yang harus digarisbawahi adalah selama partisipasi dari golongan masyarakat ini masih dimungkinkan, maka demokrasi dalam masyarakat tersebut selalu dapat dikatakan ada.

Partisipasi yang ideal dalam konteks pemilu bisa dilihat dari dua sisi. Pertama, dilihat pada sisi demand side, yakni partisipasi calon pemilih yang pandai memilih capres, caleg, serta calon kepala daerah yang memiliki kualitas dan integritas yang bagus. Jangan memilih calon yang asal populer dan bermodal kapital besar, tetapi fakir kapasitas, kapabilitas, dan integritas. Yang kedua adalah sisi supply side, yang berkaitan dengan partisipasi untuk mendorong partai, sebagai salah satu pilar demokrasi, menjadi penyedia pejabat politik yang punya integritas dan kompetensi. Jika pemilih makin kritis, cerdas,

A. Budiman, Kebebasan, Negara, Pembangunan (Jakarta: Freedom Institute, 2006), h. 3. 
serta rasional, tetapi caleg atau kepala daerah yang ditawarkan partai berkualitas buruk, tentu output-nya akan buruk.

Partai politik harus menangkap sinyalemen rasa muak rakyat terhadap elite politik lama. Saat ini rakyat sedang "memberontak" mencari pemimpin alternatif. Namun, demokratisasi akan tercederai jika parpol hanya mengedepankan figur untuk mengeruk suara dan tidak mementingkan program membangun bangsa ke depan.

Saat ini rakyat tidak sekadar membutuhkan pemimpin dengan gagasan-gagasan besar. Rakyat butuh pemimpin yang langsung menyentuh kebutuhan mereka. Tanda zaman menunjukkan, rakyat membutuhkan pemimpin berkarakter jujur, memiliki integritas, dan menghargai pluralitas.

Faktanya, harus diakui masih ada garis disparitas yang amat lebar antara dassein (yang diidealkan dan diharapkan) dengan dassollen (kenyataan empirik di lapangan). Ramdansyah, ${ }^{4}$ mengemukakan sebuah data bahwa pada pemilu tahun 2009, berbagai penyelewengan berupa aroma kecurangan dan manipulasi politik tercium sangat kuat. Pada pemilu 2004 kecurangan terjadi. Namun parahnya, pada pemilu 2009 fenomena itu meningkat lebih dramatis. Sebagai perbandingan, pelanggaran administrasi pemilu 2004 sebanyak 8.946 kasus, naik 15.341 kasus pada tahun 2009. Delik pidana pemilu dari 3.152 kasus tahun2004 melambung menjadi 6.019 kasus pada tahun 2009 .

Seperti tak pernah belajar dari pengalaman, pemilu legislatif tahun 2014 pun tak pernah sunyi dari masalah. Malah ditengarai semakin massif dan melibatkan berbagai aktor yang mempunyai kepentingan terhadap hasil pemilu, mulai dari partai politik, calon legistatif, serta penyelenggara pemilu. Modus kecurangan pun lebih sistematik, rapi dan canggih. Maka tak heran, sejak loket pengaduan sengketa pemilu dibuka oleh Mahkamah Konstitusi (MK) sudah terhitung 702 gugatan masuk ke meja MK.

Sebagai ilustrasi, sebanyak 13 ketua Panitia Pemilih Kecamatan (PPK) di Pasuruan, Jawa
Timur, dilaporkan oleh seorang anggota caleg untuk DPRD setempat telah menerima uang dari dirinya sejumlah Rp. 116 juta. Caleg dari Partai Gerindra ini dijanjikan akan mendapat penggelembungan suara pada pemilu 9 April lalu.

Di Blitar, seorang ketua kelompok penyelenggara pemungutan suara (KPPS) dipecat secara tidak hormat oleh KPUD setempat karena terbukti melakukan kecurangan. Dia terbukti mencobloi 110 surat suara untuk seorang caleg DPRD kabupaten itu. beda lagi di Kotawaringin, Kalimantan Tengah, seorang anggota KPUD di Kabupaten itu dilaporkan oleh seorang caleg untuk DPRD Provinsi telah menerima uang darinya sebesar Rp. 1,2 miliar yang diberikan bertahap. Si caleg dijanjikan kemenangan di dapil Kalteng II yang meliputi Kotawaringin Timur dan Surayan.

Masih di Kalimantan, tepatnya di Kutai Timur, Kalimantan Timur, seorang anggota KPUD kabupaten tersebut oleh polisi ditetapkan sebagai tersangka menerima uang sebesar Rp. 55 juta dari sejumlah caleg untuk menggelembungkan olehan suara mereka. Caranya, dengan mengubah isi laporan penghitungan suara pada Formulir DB-1.

Kalau mau dipaparkan selengkapnya, maka halaman ini tidak akan cukup hanya untuk menuliskan praktik-praktik politik uang yang terjadi antara penyelenggara pemilu dan peserta pemilu yaitu para caleg.

Kebusukan dan kebohongan politik, konflik kepentingan serta lakon korupsi sudah begitu merata sehingga masyarakat tak tahu siapa lagi yang dapat dipercaya. Perilaku politisi kita tak ubahnya seperti Kepiting. Apa yang khas dari Kepiting? Jika anda berhasil menangkap banyak Kepiting lalu ditaruh di dalam panci atau keranjang tak usah khawatir Kepiting akan pergi meski tidak ditutup. Karena Kepiting memiliki sifat politik bumi hangus: mati satu, mati semua; selamat satu, selamat semua. Jika ada Kepiting dalam keranjang yang hendak keluar memisahkan diri, Kepiting lain akan menyeret dan menahannya dari belakang. Kepiting punya rasa solidaritas negatif. 
Para aktivis politik yang semula gigih memperjuangkan politik bersih, ketika sudah masuk dalam mesin pemerintahan mudah terjangkit political myopic, yakni penyakit mental yang tidak mampu lagi melihat visi politik jauh ke depan, yang melewati batas usianya. Dengan kata lain political myopic hanya berpikir dan mengejar kepentingan hari ini karena mata hati dan intelektualnya tertutup sehingga tidak mampu melihat kepentingan masa depan bangsa.

Politik kadang picik dan licik. Kita kerap menderita karena ulah politik para elite, pejabat publik, dan politisi mengingkari masa kekuasaan. Mereka tak melakoni politik dengan etika public. Kekuasaan diraih dengan pengabaian hukum, etika, dan nilai-nilai kemanusiaan. Indonesia kentara mengalami defisit keluhuran dalam politik.

Dalam skala yang lebih luas, fenomena ini telah menstimulus masyarakat untuk menggugat demokrasi. Pasalnya, dalam pandangan para penggugat itu, setelah lebih dari satu dekade proses demokratisasi kondisi Indonesia dianggap tak lebih baik. Di sejumlah hal terdapat paradoks antara yang satu dengan yang lain.

Hal ini dapat dipahami mengingat demokrasi itu bukanlah sesuatu yang statis, ia fluktuatif. Huntington, ${ }^{5}$ mengemukakan bahwa sebagai sebuah kontruksi mental, keyakinan terhadap demokrasi sama dengan naik-turunnya level keimanan kita.

Jared Diamond pernah memotret salah satu indikator kegagalan demokrasi di suatu bangsa. Yakni, ketika partai politiknya terjebak dalam orientasi memperoleh kekuasaan politik (seize political power) semata ketimbang memberikan kontribusi bagi pendidikan budaya politik masyarakat. Seiring dengan ini, ketiadaan kesadaran dan sikap kritis parpol dalam menyingkap persoalan sosial mau tak mau telah mengekalkan doxa (ide absolut) parpol pada kekuasaan semata. Terkait ini, Paulo Freire sempat khawatir, bahwa kekuasaan tanpa kesadaran kritis melawan penindasan yang dialami rakyat adalah keterancaman bagi

5 Samuel P. Huntinton, The Third Wave: Democratization In The Late Twentieth Century, (Norman: University Of Oklahoma Press, 1993).

150 Copyright (C) 2015, SOSIO DIDAKTIKA, p-ISSN: 2356-1386, e-ISSN: 2442-9430 lumpuhnya nilai demokrasi.

Kekelaman itu pula yang terjadi di negaranegara di Amerika Latin (Kolombia, Equador, Venezuela, Argentina). Para politisi sayap kiri (yang berslogan pro-rakyat) mempraktikkan demokrasi yang masih amat superfisial. Di negara-negara tersebut demokrasi yang menonjol adalah demokrasi sloganisme berbasis hitung-hitungan pencitraan yang malah memicu revolusi dan pertumpahan darah.

Apa pun bentuk dan kekurangannya, konsolidasi demokrasi yang sedang kita jalani diharapkan memberi solusi bagi kedangkalan spirit bernegara. Yakni, mengembalikan kepercayaan, solidaritas, kesamaan nasib yang menjauh dari kepribadian bangsa. Ini penting di tengah menguatnya politik mirip gaya diktator Amerika Latin. Para elit kita terkesan seperti hacienderos, memerintah untuk kepentingan dirinya sendiri. Sikap mental ini berpotensi merenggut inisiasi pelembagaan demokrasi yang dijalankan dari pusat sampai daerah.

Oleh karena itu, kita memerlukan etika publik sebagai pendasaran hidup dalam pemartabatan demokrasi. Haryatmoko, ${ }^{6}$ mengartikan etika publik terkait dengan pelayanan publik, berurusan dengan integritas publik para pejabat.

Kita perlu menegakkan etika publik demi misi: (1) menangani masalah korupsi; (2) membantu pejabat publik dalam menghadapi dilemma etika dan profesionalitas; (3) mengintegrasikan nilai-nilai etika di dalam pengambilan keputusan; (4) menghadapi logika pasar dalam mengarahkan pelayanan publik. Seruan itu mengandaikan kita memiliki komitmen dan sadar etika saat turut member kontrol atas kinerja aparat pemerintah dan ulah politisi. Kita memiliki hak untuk andil dalam membenahi kondisi politik berlandaskan kemauan etis. Suseno, ${ }^{7}$ menekankan bahwa etika publik pantas disemaikan berbarengan dengan penyadaran etika politik sebagai jelmaan dimensi politis manusia dalam legitimasi kekuasaan.

\footnotetext{
6 Haryatmoko, Etika Publik. Untuk. Integritas Pejabat Publik dan Politisi, (Jakarta: Gramedia, 2011).

7 F. M. Suseno, Etika Dasar: Masalah-masalah Pokok Filsafat Moral, (Yogyakarta: Kanisius, 1993)
} 
Kita mungkin jemu dan muak serta pesimistis meladeni sekian kasus korupsi dan konflik kepentingan di tampuk kekuasaan. Agenda berbangsa dan bernegara seolah disesaki dengan praktek kecurangan, perampokan, kelicikan, dan penghinaan.

Etika perlu diumumkan kembali sebagai ajakan merefleksikan nasib Indonesia. Haryatmoko, ${ }^{8}$ memberi refleksi kritis bahwa etika memiliki nilai berdasarkan konsekuensikonsekuensi sistem demokrasi untuk menyelesaikan masalah korupsi, kekerasan, pelanggaran HAM, dan diskriminasi sosial. Politik memerlukan etika sebagai keniscayaan menggerakkan demokrasi di Indonesia. Demokrasi adalah jelmaan etika dalam politik.

Sungguh sebuah tugas yang tidak mudah ditengah-tengah menyeruaknya budaya "wani piro" di masyarakat kita. Kultur politik masyarakat kita begitu pragmatis dan transaksional. Di tengah situasi kemiskinan yang menjerat sebagian besar rakyat yang notabene menjadi pemilik suara dalam pemilu, seringkali mereka gampang tergoda dan tergiur dengan iming-iming uang politik yang dengan amat sadar digelontorkan oleh para politisi berhati jahat dan busuk. Dampak politik akibat proses pemilu yang sarat dengan politik uang adalah lahirnya sosok pemimpin transaksional yang amat rentan menggunakan kekuasaan dan wewenangnya untuk kepentingan pribadi dan kelompoknya. Mereka sengaja menggunakan siasat dagang yang membelanjakan logistik politiknya untuk mendapatkan keuntungan di tengah kemiskinan yang menjerat rakyat.

Pertanyaannya sekarang, kapan optimisme bangsa itu bisa kembali tumbuh di tengah situasi budaya politik yang korup dan transaksional seperti saat ini? Ada yang menyatakan bahwa Pemilu 2014 merupakan momentum yang tepat untuk melakukan sebuah perubahan besar sehingga sikap optimis itu setidak-tidaknya bisa membayang di setiap kepala. Pandangan semacam ini, dalam pandangan saya, memang tidak salah. Pemilu memang bisa dijadikan sebagai media politik yang dianggap paling "demokratis" untuk memilih calon pemimpin dan wakil rakyat yang amanah, berintegritas tinggi, dan negarawan ulung.

Pemilu 2014 sesungguhnya merupakan saat yang tepat untuk mempertahankan atau mengganti para pelaku politik dan menyempurnakan sistem. Orang- orang ditentukan oleh para pemilih. Sistem ditentukan oleh orang-orang yang terpilih dan gagasangagasan yang ditawarkan. Pemilu mestinya menjadi alat yang tepat untuk mengawali perbaikan kondisi bangsa dan negara.

Akhirnya, demokrasi tak sepatutnya menjadi "kambing hitam". Demokrasi bukan creation ex nibilo, sesuatu yang secara simsalabim tercipta dari kenihilan. Namun, demokrasi mesti dipandang sebagai ikhtiar, proses pembelajaran yang terus berlangsung dan paripurna. Dengan kemungkinan salah di dalamnya, tapi dengan tetap menempatkan suara rakyat di tempat tertinggi.

\section{B. Demokrasi Terjajah}

Undang-Undang Dasar 1945 telah mengamanatkan kepada bangsa Indonesia untuk melembagakan sistem demokrasi sosial atau sosio-demokrasi. Dalam sistem demokrasi seperti itu, kedaulatan rakyat tidak hanya ditegakkan dalam bidang politik, tetapi juga dalam bidang ekonomi. Bung Hatta pernah mengemukakan, "Jika di sebelah demokrasi politik belum terdapat demokrasi ekonomi, rakyat belum merdeka." 9

Amanat melembagakan demokrasi ekonomi dijabarkan melalui ketiga ayat asli dalam Pasal 33 UUD 1945: (1) Perekonomian disusun sebagai usaha bersama berdasar atas asas kekeluargaan; (2) Cabang-cabang produksi yang penting bagi negara dan yang menguasai hajat hidup orang banyak dikuasai oleh negara; serta (3) Bumi, air, dan segala kekayaan yang terkandung di dalamnya dikuasai oleh negara dan dipergunakan bagi sebesar-besarnya kemakmuran rakyat.

Namun, sebagaimana berlangsung sejak 17 Agustus 1945, amanat melembagakan sistem demokrasi sosial itu terus-menerus ditentang pihak kolonial dan kaki tangannya. Dalam 2012, h. 7 .

8 Haryatmoko, Ibid. 
rangka itu, selama 67 tahun belakangan ini, pihak kolonial telah melancarkan berbagai subversi untuk menelikung amanat UUD 1945 itu.

Secara ringkas, rangkaian subversi yang dilakukan pihak kolonial menelikung pelembagaan sistem demokrasi sosial itu adalah: (1) melancarkan Agresi I dan II dalam 1947-1948; (2) memaksakan tiga syarat ekonomi melalui penandatanganan kesepakatan KMB pada 1949; (3) melakukan destabilisasi ekonomi-politik melalui pemberontakan PRRI/Permesta pasca-pembatalan KMB pada 1956; (4) menyelundupkan beberapa ekonom Indonesia ke AS untuk mempelajari kapitalisme; (5) mendelegitimasi pemerintahan Soekarno melalui peristiwa G30S pascapenerbitan UU No 16/1965; (6) memaksa Soekarno menandatangani UU No 7, 8, 9/1966 dan UU No 1/1967 memulihkan KMB; (7) menyokong terbentuknya sebuah pemerintahan kontra-revolusioner pada 1967; (8) melakukan liberalisasi tahap pertama melalui pelaksanaan deregulasi dan debirokratisasi pada 1982; (9) melakukan liberalisasi tahap kedua melalui penandatanganan LOI pada 1998; serta (10) memulai proses legalisasi neokolonialisme melalui penerbitan beberapa produk perundangundangan yang bertentangan dengan amanat UUD 1945.

Di satu sisi, rangkaian subversi neokolonialisme itu tidak hanya berakibat pada terhalangnya proses pelembagaan sistem demokrasi sosial di Indonesia. Tindakan itu menjerumuskan bangsa ini ke dalam kondisi yang saya sebut sebagai keterjajahan permanen. Transformasi yang dialami Indonesia dalam 67 tahun sesungguhnya tidak lebih dari transformasi dari kolonialisme menuju neokolonialisme.

Di sisi lain, yang tampil mencolok pascapenandatanganan LOI pada 1998, proses pelembagaan demokrasi di Indonesia melenceng ke arah pelembagaan sistem demokrasi liberal atau demokrasi korporasi.

Artinya, dalam era demokrasi terjajah seperti saat ini, yang terjadi tak lagi sekadar semakin dalamnya cengkeraman kapitalis asing di sini. Kekuatan kapital kini menjadi faktor dominan dalam memengaruhi perkembangan ekonomi-politik di Tanah Air, baik dalam proses perebutan kekuasaan maupun dalam proses penyusunan perundang-undangan dan perumusan kebijakan.

\section{Dimanakah Peran Pemuda?}

Sampai di sini, rasanya kita sulit menampik kenyataan bahwa demokrasi kita sedang mengalami titik kritis. Demokrasi kita mengalami kondisi darurat pertolongan (SOS). Perlu langkah-langkah kolektif dan sistematis untuk menyelamatkan demokrasi kita dengan cara menghentikan tindakan anarkistis pihakpihak tertentu yang coba memangkas dan melucuti hak-hak dasar warga.

Dalam konteks inilah pemuda seharusnya berperan. pemuda patut mengoreksi dan mengawal proses demokrasi agar tidak tertelikung oleh kepentingan politik pragmatis. Meminjam istilah Fadjroel Rachman dalam Umbu T. W, ${ }^{10}$ tahap pertama revolusi demokrasi adalah saat tumbangnya kekuatan Orde Baru oleh kekuatan progresif mahasiswa. Tahap revolusi kedua merupakan penentu konsolidasi politik kekuasaan ke dalam agenda praksis pemerintahan.

Pada revolusi kedualah setidaknya pelaksanaan demokrasi menyisakan tema penting yang harus dibenahi, terutama dalam konteks institusionalisasi kepemimpinan nasional. Pertama, perlu disiapkannya strategi politik akomodatif terhadap munculnya alternatif kepemimpinan menjelang pemilu 2014 untuk mengganti wajah-wajah politisi lama yang terbebani dengan sejarah silam. Sebab kita tidak ingin keluaran pemilu 2014 nanti gagal menunjukkan kualitasnya karena pemain-pemain politiknya hasil political laundering dari sisa-sisa elit lama. Mereka berhasil mereinkarnasi dirinya karena diuntungkan efek modernisasi strategi pencitraan dan penguasaan media komunikasi politik secara masif.

Kedua, partai politik harus konsisten menghadirkan sistem internal partai yang akomodatif terhadap kepemimpinan muda

10 U. T. W. Pariangu, "Penyakit Demokrasi Kita". Jawa Pos, Edisi 16 Januari 2012, h. 4. 
(main political leadhership) untuk menjamin berjalannya sirkulasi kepemimpinan nasional secara teratur. Terjerumusnya kaum muda dalam sindikat korupsi, seperti yang dialami Gayus maupun Nazaruddin ataupun kasus rekening gendut para PNS muda, mestinya juga menjadi bahan refleksi. Tidak saja bagi birokrasi tetapi juga bagi partai politik untuk membenahi dirinya.

Kita memang sudah berada di panggung demokrasi terbuka dalam kurun 15 tahun. Namun, kita dituntut pula untuk terus melakukan resolusi dan pembenahan yang serius terkait karakter ideologi demokrasi. Dalam banyak hal, kita masih gagal membuka kemungkinan dan alternatif dalam mengelola sirkulasi kepemimpinan yang prospektif dan sesuai dengan kebutuhan demokrasi. Perubahan fundamental untuk melengkapi demokrasi itu perlu dilakukan demi lahirnya nilai-nilai kemanfaatan bersama.

\section{Pemuda: Pemimpin Generasi Masa Depan}

Harus diakui bahwa kepemimpinan nasional kita hari ini masih didominasi oleh figur-figur senior yang kemudian memunculkan keputusasaan dari sejumlah tokoh muda akan peranan mereka dalam kehidupan bernegara. Keputusasaan itu antara lain muncul dari berkembangnya sejumlah pernyataan yang cenderung meragujan kemampuan kaum muda dalam menjalankan peran-peran sentral di tingkat masyarakat.

Bahkan, tidak hanya dalam dunia politik, dalam kehidupan yang lain, misalnya pendidikan, orang-orang muda juga masih sering dipandang sebelah mata. Ada satu logika yang kadangkadang sulit dipahami dalam konteks masyarakat Indonesia menyangkut peranan kaum muda. Di satu sisi, terdapat pengakuan bahwa "muda" biasanya identik dengan kecerahan, kelincahan, kekayaan ide, kreativitas, dan kegigihan. Tetapi pada saat yang bersamaan, pengakuan itu lebih banyak berlangsung pada level kognisi, sehingga ada disparitas yang cukup nyata antara pengakuan itu dan praktik yang terjadi. Tegasnya, sementara pengakuan diberikan, kesempatan jarang diberikan kepada kaum muda.

Karena itu, anggapan terhadap kaum muda pun kemudian bergeser menjadi label-label yang kurang positif. Boy, ${ }^{11}$ mencontohkan, misalnya, muda adalah cerminan minimnya pengalaman dan absennya kematangan. Dalam konteks tertentu, hal-hal tersebut memang mendapatkan pembenaran, tetapi menjadikan alasan-alasan yang sebenarnya lebih banyak didominasi oleh asumsi ketimbang fakta ini sebagai halangan tampilnya kaum muda ke dalam kancah kepemimpinan publik menjadi sangat naif.

Posisi pemimpin sangat penting bagi kehidupan sebuah bangsa. Dampaknya akan sangat memengaruhi perjalanan bangsa yang dipimpinnya. Kebijakan seorang pemimpin memang sangat berkaitan langsung dengan nilai kemaslahatan. Sederhananya, kemaslahatan berarti kebajikan atau kebaikan yang bisa dirasakan sebanyak-banyaknya orang yang dipimpin. Karena itu, pemimpin dan kemaslahatan tidak bisa dipisahkan satu sama lain. Jika dipisahkan, pemimpin akan kehilangan fungsi utamanya. Keberadaannya tidak memberikan manfaat apa pun kepada orang-orang di bawah kepemimpinannya.

Berbagai sistem untuk menentukan pemimpin sudah banyak dikenal selama ini. Salah satunya demokrasi. Dalam sistem demokrasi, pemimpin ditentukan melalui mekanisme pemilihan yang melibatkan setiap individu warga masyarakat. Masyarakat diberi kesempatan untuk menggunakan haknya guna ikut menentukan siapakah pemimpin yang mereka inginkan.

Pemilihan Umum Presiden pada 9 Juli 2014 tahun yang lalu merupakan salah satu contoh praktik demokrasi yang memberikan kesempatan kepada rakyat di negeri ini untuk menentukan pemimpin untuk lima tahun ke depan. Semua warga yang memiliki hak suara diberi kesempatan yang setara untuk memberikan suara dan menyalurkan aspirasi politiknya melalui pemilihan langsung.

Kita semua patut bersyukur terhadap perkembangan tersebut. Ada perbaikan dalam

11 P. B. ZTF, Semua Umatku masuk, Surga, Kecuali ..., (Sidoarjo: Masmedia Buana Pustaka, 2009). 
proses penentuan presiden sebagai pemimpin tertinggi di negeri tercinta ini. Kita masih ingat, pada masa Orde Baru, rakyat tidak diberi kesempatan setara untuk menentukan presiden. Saat itu presiden hanya ditentukan melalui mekanisme pemilihan di parlemen. Siapa yang bisa menguasai perlemen, dialah yang memiliki kesempatan terbesar untuk memenangi pemilihan presiden.

Artinya, dari sisi prosedur, perkembangan demokrasi kita sudah menuju ke arah yang lebih baik jika dibandingkan dengan masamasa sebelumnya. Partisipasi warga dihitung untuk menjadi penentu akhir kemenangan atau kekalahan. Kondisi tersebut sangat berbeda dengan masa sebelumnya yang lebih mendasarkan pada mekanisme perwakilan rakyat di parlemen. Padahal, sangat sering terjadi, mekanisme perwakilan itu justru tidak mencerminkan aspirasi warga yang diwakili.

Melihat kenyataan tersebut, rasa syukur kita tidak boleh berhenti pada prestasi yang dipertunjukkan demokrasi prosedural ini. Kita memang mensyukuri bahwa setiap suara yang diberikan warga dipakai sebagai penentu kemenangan dan kekalahan calon pemimpin bangsa ini. Suara mereka semua ikut menentukan pemimpin mereka.

Namun, kita semua patut bertanya, untuk apa demokrasi prosedural tersebut? Apa pentingnya bagi perbaikan kehidupan masyarakat? Karena itu, yang perlu didorong sekarang, dari prestasi demokrasi prosedural tersebut, kita bersama-sama bisa berlari cepat menuju demokrasi substansial.

Demokrasi prosedural tidak boleh dijadikan tujuan. Demokrasi prosedural hanya menjadi alat untuk meningkatkan partisipasi warga dalam proses penting yang berhubungan dengan penentuan kehidupan bersama.

Orientasi kemaslahatan harus menjadi proses berikutnya dari prestasi kita bersama dalam memantapkan demokrasi prosedural. Proses-proses demokrasi kita patut dijalankan demi kepentingan sebesar-besarnya kemakmuran dan kesejahteraan rakyat. Aspirasi yang sudah diberikan warga dalam pemilu patut direspons pemimpin yang lahir dari proses demokrasi ini melalui program peningkatan kemakmuran serta kesejahteraan rakyat secara bersama.

Kemakmuran dan kesejahteraan tersebut memiliki arti luas. Kesejahteraan ekonomi dan kemakmuran material hanyalah salah satu arti yang sangat luas itu. Pemimpin memang tidak boleh meremehkan pentingnya kesejahteraan ekonomi dan kemakmuran material rakyatnya.

Orang biasa berkata, buat apa demokrasi kalau ternyata kehidupan rakyat tetap miskin dan tidak ada perbaikan. Itulah tantangan demokrasi. Karena itu, pemimpin yang lahir dari proses demokrasi, menurut al-faqir, sebaiknya segera berpikir keras untuk menjadikan amanah yang diperolehnya sebagai kesempatan untuk mengabdi kepada rakyat melalui program pengembangan kesejahteraan ekonomi dan kemakmuran material mereka.

Di pundak pemimpin yang dimaksud, ada tanggung jawab besar untuk meyakinkan rakyat bahwa demokrasi adalah untuk kepentingan perbaikan kualitas kehidupan mereka. Kalau pemimpin tidak mampu menjalankan amanah penciptaan kesejahteraan ekonomi dan kemakmuran rakyat secara merata serta berkeadilan, rakyat kemudian bisa saja menyangsikan manfaat demokrasi. Mereka bisa mengidolakan kembali masa-masa sebelum berkembangnya demokrasi. Itulah yang menjelaskan munculnya poster dan selebaran belakangan ini seperti piye kabare, enak jamanku to?

Pemimpin juga sebaiknya berpikir keras guna menjadikan amanah yang diperolehnya untuk perbaikan kualitas kehidupan nonmaterial kita bersama. Pengembangan nilai-nilai luhur yang lama menjadi ciri khas kita sebagai sebuah bangsa seharusnya mendapat perhatian khusus.

\section{E. Penutup}

Sejak tahun 1967 sampai era mutakhir, Indonesia memainkan peranan dalam menggerakkan kekuatan-kekuatan pasar internasional untuk kehidupan ekonomi. Dibutuhkan perumusan konsep-konsep politik yang sungguh-sungguh dapat secara 
mendasar mengungkapkan bentuk dan prosedur politik yang paling memungkinkan pengembangan sistem politik demokrasi yang sanggup memelihara kehidupan sosial budaya yang tenteram, tetapi juga secara mendasar menggerakkan pertumbuhan ekonomi yang kuat, cepat dan merata.

\section{F. Daftar Pustaka:}

Baswir, Revrisond. (2012). Demokrasi Terjajah. Kompas. 21 Mei. Halaman 7. Jakarta.

Budiman, A. (2006). Kebebasan, Negara, Pembangunan. Jakarta: Freedom Institute.

Haryatmoko. (2011). Etika Publik Untuk Integritas Pejabat Publik dan Politisi. Jakarta: Gramedia.

Huntinton, Samuel. P. (1993)). The Third Wave: Democratization In The Late Twentieth Century. Norman: University Of Oklahoma Press.
Kunio, Yoshihara. (1987). The Rise of Ersatz Capitalism in Southeast Asia. Yogyakarta: LP3ES.

Pariangu, U. T. W. (2012). Penyakit Demokrasi Kita. Jawa Pos. 16 Januari. Halaman 4. Jakarta.

Piliang, Y. A. (2011). Parasit Demokrasi. Kompas. 6 Oktober. Halaman 6. Jakarta.

Ramdansyah (2010). Sisi Gelap Pemilu 2009, Potret Aksesori Demokrasi Indonesia. Jakarta: Rumah Demokrasi.

Suseno, F. M. (1993). Etika Dasar: MasalahMasalah Pokok Filsafat Moral. Kanisius: Yogyakarta.

ZTF, Pradana Boy. (2009). Semua Umatku masuke Surga, Kecuali .... Sidoarjo: Masmedia Buana Pustaka. 